\title{
A MAGYAR FELSŐOKTATÁS FINANSZÍROZÁSÁNAK EGYES KÉRDÉSEI
}

\section{THE HUNGARIAN HIGHER EDUCATION FUNDING FOR SOME ISSUES}

\author{
Fregan Beatrix ${ }^{1}$, Sótonyiné Zsigmond Ágnes ${ }^{2}$, Szabó Terézia ${ }^{3}$ \\ ${ }^{1}$ Nemzeti Közszolgálati Egyetem, Cím: 1101 Budapest, Hungária krt. 9-11., \\ levelezési cim, fregan.beatrix@uni-nke.hu \\ 2Óbudai Egyetem,Bánki Kar, levelezésicim,sotonyi.agnes@bgk.uni-obuda.hu \\ ${ }^{3}$ Óbudai Egyetem, Bánki Kar, levelezési cím, szabo.terezia@bgk.uni-obuda.hu
}

\begin{abstract}
Over the past 25 years, Hungary has transformed higher education, the academic studies has broadened access, amended several times, re-regulated the Higher Education Act, and previously excluded groups in the years after the change of regime taken the desired degree, realized the freedom of education, developed the Hungarian system of institutions of higher education and training structure. Unified view of the unity of teaching and research, demand began to improve the quality of higher education. The authors of the publication were undertaken to the literature - a summary of key findings based on the strategy in higher education.
\end{abstract}

Keywords: higher education, education finance, quality of higher education

\section{Összefoglalás}

Az elmúlt 25 év alatt Magyarország átalakította felsőoktatását, az egyetemi tanulmányokhoz a hozzáférést kiszélesítette, újra szabályozta a felsőoktatási törvényt, átalakította a szakokat, és a korábban kizárt csoportok a rendszerváltozást követő években megszerezhették a kívánt diplomát, megvalósult a tanítási szabadság, kialakult az egységes magyar felsőoktatás intézményrendszere és képzési szerkezete. Egységes képet ad az oktatás és kutatás egysége, megindult a felsőoktatás minőségi fejlesztésének igénye. A publikációban a szerzők arra vállalkoznak, hogy a szakirodalom - elsődlegesen a Fokozatváltás a felsőoktatásban - alapján összefoglalják a stratégia legfontosabb megállapításait.

Kulcsszavak: felsöoktatás, finanszírozás, oktatás minöség.

\section{Bevezetés}

Az elmúlt negyed évszázad után, 2014re a magyar felsőoktatás Magyarországon az egyik legsikeresebb, legversenyképesebb ágazattá vált, és minden lehetöség adott lett arra, hogy átalakuljon az oktatás rendszere, a reformok után fokozatváltás történjen a képzésekben. [1].

\section{Melyek lettek az új követelmé- nyek?}

- a hazai felsőoktatásnak meg kell közelítenie a nemzetközi képzési színteret, fel kell vennie a megkívánt tempót;

- az értékmegőrzés és értékteremtés követelményeinek teljesülése;

- az erőforrások hatékony felhasználása 
- egyre magasabb minőséget nyújtó képzési rendszer kialakítása

A felsőoktatás átalakítása mellett a finanszírozás problémakörét és át kell tekinteni. Olyan időszakban vagyunk, amikor a szükséges pénzügyi feltételek változatlan állami szerepvállalás mellett, külső többletforrások bevonására ma nagyobb a szükség, mint korábban, mert stratégiai cél, hogy a felsőoktatás eltartsa magát az állami pénzügyi források kiegészítésével. Távlati célként társadalmi elvárás is egyben, hogy 2030-ra egy biztos alapokon nyugvó, nem pusztán állami forrásokból finanszírozott felsőoktatás müködjön, és az új rendszer a minőségi oktatásnak és versenyképes képzésnek köszönhetően képes lesz külső források bevonásával is finanszírozni tevékenységét.

A külső források megszerzésében támogató erőként jelentkezhet a globalizáció, a gyors technológiai fejlödés, és bár a demográfiai folyamatok csökkenő bekerülő hallgatói létszámot feltételeznek, a változó társadalmi igények továbbra is nagy kihívás elé állítják a felsőoktatást. Az oktatási rendszernek igazodnia kell a gazdasági és munkaerőpiaci igényekhez, a társadalmi elvárásokhoz éppúgy, mint a kutatásfejlesztési és innovációs folyamatokhoz.

\subsection{Milyen programokkal lehet vál- toztatni a rossz tendencián?}

- Egyes vélemények szerint a lehető leghamarabb be kell vezeti az emelt szintü érettségi követelményét a bekerüléshez legalább egy, alapozást segítő természettudományi tantárgyból;

- Folyamatosan elökerül szakmai berkekben, hogy a természettudományi szakokon a felvételi ponthatár-minimumot meg kell emelni, ezzel csökkentve a lemorzsolódott, sikertelenül teljesítő és az állami rendszer finanszírozását élvező, de diploma nélkül „eltartott” hallgatói létszámot;
-A középiskolai ismeretszintet folyamatosan emelni szükséges, a természettudományi tárgyak vonatkozásában, növelni kellene a természettudományos tantárgyak (matematika, fizika, kémia) óraszámát, illetve a specializálódó, a természettudományi továbbtanulásra felkészítő tagozatok számát;

- Ugyanakkor emelni szükséges a természettudományos tanárképzés színvonalát, ami megalapozhatja a jövő nemzedék középiskolai tudásszintjének emelkedését is;

\section{A felsőoktatás finanszírozásá- nak egyes alapelvei}

A Kormány által elvárás a felsőoktatási intézmények finanszírozási feladataik keretében az alaptevékenységeik, oktatási és kutatási tevékenységeik során egyre nagyobb mértékben támaszkodjanak saját bevételeikre, külső, piaci forrásokra.

Ennek elméleti jelentősége lehet, hogy a külső bevételi források beintegrálásával csökkenhet függőségük a mindenkori költségvetési források kiszámíthatatlanságától. A költségvetési gazdálkodás jelenlegi, szigorú szabályozási környezetében megjelenő anomáliák, problémák (vagyongazdálkodás, eszközbeszerzések korlátozásai, a saját bevételek felhasználására vonatkozó kötöttségek stb.) jelentős mértékben akadályozzák, ellenérdekeltté teszik az intézményeket a hatékony gazdálkodás elérésében, a fejlesztésekben.

Az önköltségkimutatás, vagyis az új, feladatalapú költségvetés tervezési és gazdálkodási rendszer bevezetése elvileg átlátható alapokra helyezi az intézményektől „megrendelt” közfeladatok ellátásának valós költségeit, elválaszthatóvá teszi azokat az üzleti, vállalkozási típusú tevékenységektöl. Bár elvi síkon, objektíven kimutatható az egyes szakok önköltsége, de ez több egyetem vonatkozásában és összehasonlításában nehezen értelmezhetö. Közgazdasági szempontokból természetesen a bevételek, 
kiadások és a hallgatói létszám alapján viszonylag könnyen kiszámolható a szakok önköltsége, de ez mégsem ilyen egyszerü. Az azonos szakokon képzést folytató egyetemek a legtöbb esetben nincsenek azonos „kiindulási” szinten. 2010 óta a megszünt szakképzési hozzájárulások hiánya és a közép-magyarországi régió pályázati forrásokból való kiesése az elmúlt években nem segítette a mérnökképzés fejlesztését. A technikai eszközök elavultsága, azok energiafaló jellege az önköltséget jelentősen emelik, rontja a versenyszellemet, hogy a régió egyes szempontok miatt hátrányból indul. Amennyiben az önköltségszámítás objektív alapokon nyugszik, úgy az állami megrendelésben hátrányból indulhat egyegy budapesti, vagy pest megyei egyetem.

Ráadásul a szigorú közgazdasági szemlélettől elszakadva, az egyetemek maguk határozzák meg az önköltségszámítás bevételi és kiadási költségeit, így nagy valószínüséggel az összehasonlítás objektíven nem végezhető el.

A műszaki képzést folytató egyetemek, karok közül az Óbudai Egyetem az oktatás minőségi színvonalának emelését a gyakorlatorientáltságban látja megtestesíteni. Stratégiájában, intézményfejlesztési céljai között első helyen szerepelteti a lehetőség kiaknázását, az ipar beépülését a képzésekbe és az innováció területén egyaránt. [2]

De hol és hogyan fog ez megjelenni a finanszírozásban? Javítja, vagy csökkenti az önköltségszámítást és ezzel az összehasonlítás esélyeit ez a minőségjavítási törekvés?

A választ csupán gazdasági szempontból, közgazdasági szemlélettel nem lehet megadni. Ehhez meg kell vizsgálni, hogy milyen körülmények befolyásolják a gyakorlatorientáltságot. Az Óbudai Egyetem a 2017 szeptemberében induló képzéseiben bevezeti a projekt alapú oktatást, amelynek egyik színtere a projektmunka tantárgy bevezetése. A tantárgy keretében a hallgatók részére kötelező a képzési ciklusban legalább egy alkalommal ezt a tárgyat felvenni és eredményesen teljesíteni.[3] Az elvárás a képzést szervező egységektől az, hogy az alapozó ismeretek megszerzését követően, a szakmai képzési blokkban legalább egy féléven keresztül tartó tantárgyat szervezzenek. A tantárgy keretében 4-6 hallgatóval számolva tervezzék a projekteket.[5] Az önköltségszámítás tehát egy olyan újabb kiadási faktort kap, ami esetlegesen más felsőoktatási intézményben nem található, így a versenyben hátrány származhat. Elönye lehet viszont, hogy a hallgatók gyakorlatias képzése újabb szinttel gyarapodik.

A közeljövőben ezekre a kérdésekre és még sok további kérdésre kell választ keresni.[6] Az önköltségszámítás vonatkozásában a projektfeladatok milyen arányban növelik a költségeket, ez hogyan fogja befolyásolni a szakok összehasonlítását más egyetemekkel, nagy valószínüséggel csak a jövő elemzései adhatnak választ.

Azonban biztosan állítható, hogy a hallgatói felkészítés új módszerei, a gyakorlati tudás szintjének emelése csupán közgazdasági szempontokból nem értékelhető, mert a tudásszint növekedés, a mielőbbi beintegrálódás a cégek életébe, mint frissen végzett mérnök, nem pénzügyi kategória.

\section{Szakirodalmi hivatkozások}

[1] Fokozatváltás a felsőoktatásban. A teljesitményelvü felsőoktatás fejlesztésének irányvonalai.

www.kormany.hu/download/d/90/30000/fels őoktatási\%20koncepció.pdf (2017.02.21.)

[2] Az Óbudai Egyetem Intézményfejlesztési terve (Szenátusi határozattal elfogadva: 2015. október)

[3] A magyarországi felsőoktatás finanszírozásának jogi háttere. Szempontok az ágazati mutatószámrendszer kialakitásához. www.felvi.hu/pub_bin/dload/AVIR/felsookt finanszirozas_jogi_hatter.pdf (2017.02.21.)

[4] Rajnai Z: A tábori alaphírhálózat vizsgálata, Nemzetvédelmi egyetemi közlemények (ISSN: 1417-7323) 2000: (1) pp. 48-57. (2000)

[5] www.parlament.hu/documents/...42.../06bb7 668-7571-4c9a-a139-086e91a0ca38 
[6] Vargha Márton Gábor: A felsőoktatási intézmények finanszírozása: trendek és statisztikák elemzése az OECD országokban valamint a Japánban és Magyarországon müködő rendszer vizsgálata. BGF Budapest, 2009. elib.kkf.hu/edip/D_14681.pdf (2017.02.21) 